УДК 620.2: 330.133.2

Н. В. ЛИСЕНКО, М. Г. МАРТОСЕНКО

Полтавський науково-дослідний експертно-криміналістичний иентр Міністерства внутрішніх справ Украӥни

\title{
ОСОБЛИВОСТІ СУДОВО-ТОВАРОЗНАВЧОЇ ЕКСПЕРТИЗИ КРУГЛИХ ЛІСОМАТЕРІАЛІВ ХВОЙНИХ ПОРІД
}

\author{
Н. В. ЛЫСЕНКО, М. Г. МАРТОСЕНКО \\ Полтавский научно-исследовательский экспертно-криминалистический иентр \\ Министерства внутренних дел Украинь

\section{ОСОБЕННОСТИ СУДЕБНО-ТОВАРОВЕДЧЕСКОЙ ЭКСПЕРТИЗЫ КРУГЛЫХ ЛЕСОМАТЕРИАЛОВ ХВОЙНЫХ ПОРОД}

\author{
N. LYSENKO, M. MARTOSENKO \\ Poltava Scientific Research Forensic Center \\ of the Ministry of Internal Affairs of Ukraine
}

\section{FEATURES OF FORENSIC EXAMINATION OF GOODS ROUND CONIFEROUS FORESTS}

\author{
https://doi.org/10.36910/6775-2310-5283-2020-13-12
}

\begin{abstract}
Мета. Дослідження теоретичних та практичних основ проведення судовотоварознавчих експертиз з метою визначення ринкової вартості лісоматеріалів, зокрема визначення чинників, щуо впливають на вартість круглих лісоматеріалів хвойних порід та обтрунтування алгоритму визначення ринкової вартості круглих лісоматеріалів хвойних порід за допомогою порівняльного методичного підходу.
\end{abstract}

Методика. Під час проведення досліджень, для визначення ринкової вартості круглих лісоматеріалів хвойних порід, в комплексі застосовувалися методи, зокрема дедуктивний - під час теоретичного узагальнення проблеми, діалектичний - при пізнанні сутності явища незаконної порубки лісу, дослідженні його загальних тендениій; монографічний - для детальної конкретизачії наукових засад визначення ринкової вартості круглих лісоматеріалів хвойних порід; індуктивний та дедуктивний - для аргументування сформульованих у ході досліджень висновків, положень та перспектив подальших досліджень.

Результати. Розглянуто питання використання спеціальних товарознавчих знань у практиџі розслідування кримінальних справ про незаконні порубки лісових насаджень. Проаналізовано механізм проведення судово-товарознавчої експертизи для визначення 
ринкової вартості круглих лісоматеріалів хвойних порід. Обтрунтовано доцільність застосування порівняльного методичного підходу під час проведення судової товарознавчої експертизи із визначенням ринкової вартості круглих лісоматеріалів хвойних порід. У статті обтрунтовано алгоритм визначення ринкової вартості круглих лісоматеріалів хвойних порід під час проведення судово-товарознавчої експертизи, який передбачає: ідентифікачію об'єкта дослідження; віднесення об'єкта дослідження до відповідного класифікаџійного угрупування; встановлення кількісних $i$ якісних характеристик об'єкта дослідження; вибір методів дослідження та проведення необхідних розрахунків; визначення ринкової вартості об'єкта дослідження за допомогою порівняльного методичного підходу; оцінка одержаних результатів проведеного дослідження з письмовим оформленням його результатів.

Наукова новизна. У роботі вперше узагальнено та викладено комплекс проблемних питань, щзо виникають при використанні спеціальних товарознавчих знань під час проведення судово-товарознавчих експертиз круглих лісоматеріалів хвойних порід.

Практична значимість. Запропонований та апробований алгоритм визначення ринкової вартості круглих лісоматеріалів хвойних порід може бути використано під час проведення подібних судово-товарознавчих експертиз.

Ключові слова: незаконні порубки, нелегальний обіг деревини, деревина, круглі лісоматеріали, товарознавча експертиза, ринкова вартість.

\section{Постановка проблеми у загальному вигляді та їі зв'язок з важливими} науковими чи практичними завданнями. Роль лісів у підтримці стабільності біосфери сьогодні є загальновизнаною. Ліси є однією з найбільш різноманітних і широко поширених екосистем на Землі. Вони виступають джерелом отримання деревини і продуктів; мають рекреаційне значення i виконують екосистемні функції, включаючи регулювання грунтового i водного режимів; об'єктами біорізноманіття та поглиначами вуглекислого газу. Надмірна експлуатація, деградація навколишнього середовища і зміна видів землекористування, лісові пожежі, неефективне лісовідновлення тощо несуть загрозу лісовим ресурсам [1]. Крім того, існує суспільна небезпека незаконної порубки лісу, яка визначається низкою чинників, серед яких: особлива цінність лісів для українського суспільства і держави; пряма загроза цілим екосистемам, включаючи цінні види флори і фауни; заподіяння істотної шкоди об'єктам природно-заповідного фонду та особливо охоронюваним лісам; заподіяння значних матеріальних збитків державі; тривалий і витратний процес відновлення лісів; поширеність таких злочинів порівняно 3 іншими посяганнями на довкілля [2]. Під час розслідувань правопорушень щодо незаконної порубки лісу, одним із важливих етапів доказування $є$ призначення комплексу судових експертиз, у тому числі судово-товарознавчих з метою 
встановлення вартості лісоматеріалів.

Аналіз останніх досліджень, у яких започатковано вирішення проблеми. Значна теоретична та методична база щодо прикладного використання судових експертиз залежно від різновиду кримінального правопорушення, що розслідується, закладена в працях Вінберга А. I., Нестерова А. В., Романюка Б. В., Шляхова А. Р., Букалова К. А., Журавля В. А., Росинської О. Р. та інших. Окремі загальні питання підготовки матеріалів та призначення судових експертиз i експертних досліджень висвітлено у Інструкціях, що затверджені відповідними наказами Міністерства внутрішніх справ України та Міністерства юстиції України.

Тактиці призначення та використання можливостей судової товарознавчої експертизи у кримінальному провадженні присвячені праці Архіпова В. В., Толмачової С. C, Петрової І. А., Шевченко О. В., Губарева В. М., Желавської О. О., Посохова А. С., Авер'янова Т. В., Моїсеєва О. М., Вилкової С. А., Селіванова А. А. та інших.

Незаконна порубка лісу досліджувалася фахівцями в галузі екологічного права, земельного права, кримінального права, криміналістики, лісівництва, проте більшість робіт стосувалися аналізу окремих питань, пов’язаних із правовим режимом лісів, охороною довкілля, спеціальним використанням лісових ресурсів, управлінням лісовим фондом України, кримінальною відповідальністю за незаконну порубку лісу, розслідуванням цього виду злочинів. Розробкою різних аспектів незаконної порубки займалися українські та закордонні науковці Єгорова Т. П., Корнякова Т. В., Скворцова О. В., Письменсього С. О., Кравця П. В., Гавриша С. Б., Дудорова О. О., Заічко О. В., Олійничука Р. П., Чуракова Д. Б., Вірясова Н. В., Шаріпова О. В., Королева А. В., Сулейманова А. Л. та інші. Разом із тим, як свідчать результати проведеного авторами дослідження, стан сучасної юридичної науки характеризує недостатнє теоретичне та практичне розв'язання низки проблем, пов'язаних із можливістю використання спеціальних знань у галузі товарознавства для швидкого, повного та всебічного розкриття й розслідування злочинів, пов'язаних із незаконною порубкою лісу, що $\epsilon$ актуальним для сучасної наукової теорії й юридичної практики.

Ціль статті полягає у розгляді теоретичних та методичних основ товарознавчих досліджень щодо особливостей визначення ринкової вартості круглих лісоматеріалів хвойних порід із використанням порівняльного методичного підходу.

Об’сктом дослідження є круглі лісоматеріали, а саме колоди дерев 
хвойних порід.

Методи дослідження. Для визначення ринкової вартості круглих лісоматеріалів хвойних порід у комплексі застосовувалися методи, зокрема дедуктивний - при теоретичному узагальнені проблеми, діалектичний - при пізнанні сутності явища незаконної порубки лісу, дослідженні його загальних тенденцій; монографічний - для детальної конкретизації наукових засад визначення ринкової вартості круглих лісоматеріалів хвойних порід; індуктивний та дедуктивний - для аргументування сформульованих у ході досліджень висновків, положень та перспектив подальших досліджень.

Виклад основного матеріалу дослідження 3 повним обгрунтуванням отриманих наукових результатів. Об'єктами судово-товарознавчої експертизи є лісоматеріали круглі листяних та хвойних порід, деревина дров’яна, лісоматеріали пиляні листяних та хвойних порід. Коло питань, що вирішуються судово-товарознавчою експертизою наступний: яким характеристикам відповідає товар згідно 3 Українським класифікатором товарів зовнішньоекономічної діяльності; до якого класу якості відносяться лісоматеріали; чи відповідає клас якості лісоматеріалів вимогам технічних умов за візуальними характеристиками; яка ринкова вартість лісоматеріалів.

У межах наукової статті проаналізовано специфіку проведення судовотоварознавчої експертизи круглих лісоматеріалів хвойних порід, зокрема запропоновано алгоритм визначення ринкової вартості круглих лісоматеріалів породи сосна.

Огляд круглих лісоматеріалів був проведений із залученням спеціалістів лісового господарства і управління лісового та мисливського господарства. На момент проведення огляду об'єкти дослідження зберігалися на відкритому майданчику, який не було очищено від сміття. Колоди були нещільно вкладені, нерівними та непаралельними рядами, не було облаштовано підштабельну основу. Об'єкти дослідження не було оброблено захисними покриттями для захисту від уражень комахами, грибних уражень та розтріскувань.

Початковим етапом товарознавчого дослідження є ідентифікація об'єктів, у ході якої встановлено, що для огляду надано круглі лісоматеріали, стовбур яких покритий корою від червоно-бурого до майже сірого кольору, 3 борозенками, із залишками деревної смоли, на торцях добре помітні річні шари. Виявлені ознаки характерні для сосни.

Відповідно до вимог чинного законодавства України, при легально проведених рубках здійснюється поколодне маркування, шляхом набиття 
уніфікованого засобу маркування із номером та відповідним штрих-кодом для обліку - бирок на торець кожної колоди. За номером кожної з них закодована інформація щодо якісних та кількісних характеристик сортименту (вид лісоматеріалу, порода, клас якості, діаметр, довжина). За номером бирки, на офіційному сайті державного агентства лісових ресурсів України Державне підприємство «Лісогосподарський Інноваційно-Аналітичний Центр» можна он-лайн перевірити не лише легальність вирубки деревини, але й ідентифікувати круглий лісоматеріал. У номері бирки закодована наступна інформація: постійний лісокористувач/власник лісів; вид продукції; діаметр; об’єм; група діаметрів; сорт/клас якості; кількість; довжина; порода. На об’єктах дослідження, бирку закріплено до торця колоди з двох протилежних країв по довжині, при цьому не порушено код у форматі «UA ДАЛРУ 000000 000» та штрих-код. Бирки виготовлено 3 полімерного матеріалу чорного кольору, а написи виконані барвником білого кольору. Зовнішній вигляд маркувальної бирки на одній із досліджуваних колод представлено на рис. 1.

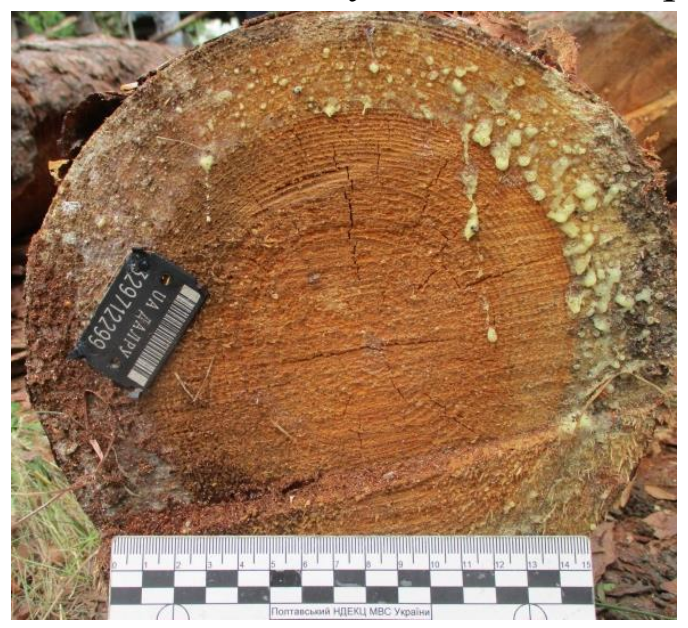

\section{Рис. 1. Зовнішній вигляд маркувальної бирки на торці колоди}

Після здійснення ідентифікації об’єктів обов’язковою є процедура віднесення об’єктів дослідження до відповідного класифікаційного угрупування. У процесі класифікації об’єктів дослідження було визначено їх належність до відповідних класифікаційних категорій, які прийняті у виробничо-торгівельній сфері. У ході товарознавчого дослідження було 3'ясовано, що об'єкти дослідження відносяться до класу промислових товарів народного споживання; підкласу - продукція сільського господарства, лісового господарства та рибного господарства; групи - продукція лісового господарства, лісозаготівлі та послуги, пов’язані з лісівництвом; підгрупи деревина необроблена; групи - колоди дерев хвойних порід [3]. 
На етапі встановлення кількісних і якісних характеристик об'єктів дослідження був здійснений аналіз зовнішнього вигляду та фактичного стану об'єктів. Огляд круглих лісоматеріалів був проведений із залученням спеціалістів лісового господарства і управління лісового та мисливського господарства, які здійснили вимірювання розмірів (серединний діаметр, довжина) із фіксуванням візуальних характеристик (ознак окремих ділянок лісоматеріалу, що впливають на якість деревини і обмежують можливості їі використання).

Довжину кожної колоди вимірювали за допомогою рулетки вимірювальної як найкоротшу відстань між двома паралельними площинами, що розташовані на кожному з торців колод, які охоплюють повний переріз і $є$ перпендикулярними до поздовжньої осі колоди. Серединний діаметр кожної колоди 3 корою вимірювали за допомогою лісової вимірювальної вилки як відстань між двома паралельними прямими, дотичними до круглого лісоматеріалу.

Об'єм колод без кори за серединним діаметром колод 3 корою було обчислено із використанням таблиць відповідно до ДСТУ 4020-2-2001 (prEN 1309-2:1998) Лісоматеріали круглі та пиляні. Методи обмірювання та визначення об'ємів. Частина 2. Лісоматеріали круглі. Виходячи 3 вищевикладеного, кожна колода була класифікована за розмірами відповідно до вимог ДСТУ EN 1315-2-2001 Класифікація за розмірами. Частина 2. Круглі лісоматеріали хвойних порід. Результати класифікації об'єктів дослідження за розмірами представлено в таблиці 1.

Таблиця 1

Класифікація за розмірами об'єктів дослідження

\begin{tabular}{|c|c|c|c|c|c|}
\hline $\begin{array}{c}\text { № } \\
\text { з/п }\end{array}$ & $\begin{array}{c}\text { Довжина } \\
\text { колоди, м }\end{array}$ & $\begin{array}{c}\text { Серединний діаметр } \\
\text { колоди з корою, см }\end{array}$ & $\begin{array}{c}\text { Об’єм колоди } \\
\text { без кори, } \mathbf{m}^{3}\end{array}$ & $\begin{array}{c}\text { Клас за } \\
\text { діаметром }\end{array}$ & $\begin{array}{c}\text { Клас за } \\
\text { довжиною }\end{array}$ \\
\hline 1 & 2 & 3 & 4 & 5 & 6 \\
\hline 1. & 4,5 & 23 & 0,167 & D2a & L2 \\
\hline 2. & 4,5 & 24 & 0,182 & D2a & L2 \\
\hline 3. & 4,5 & 22 & 0,153 & D2a & L2 \\
\hline 4. & 4,5 & 23 & 0,167 & D2a & L2 \\
\hline 5. & 4,5 & 23 & 0,167 & D2a & L2 \\
\hline 6. & 4,5 & 22 & 0,153 & D2a & L2 \\
\hline 7. & 4,5 & 24 & 0,182 & D2a & L2 \\
\hline 8. & 4,5 & 23 & 0,167 & D2a & L2 \\
\hline 9. & 4,5 & 21 & 0,139 & D2a & L2 \\
\hline
\end{tabular}


Продовження табл. 1

\begin{tabular}{|c|c|c|c|c|c|}
\hline 1 & 2 & 3 & 4 & 5 & 6 \\
\hline 10. & 4,5 & 24 & 0,182 & D2a & L2 \\
\hline 11. & 4,5 & 22 & 0,153 & D2a & $\mathrm{L} 2$ \\
\hline 12. & 4,5 & 21 & 0,139 & D2a & $\mathrm{L} 2$ \\
\hline 13. & 4,5 & 21 & 0,139 & $\mathrm{D} 2 \mathrm{a}$ & L2 \\
\hline 14. & 4,5 & 22 & 0,153 & D2a & L2 \\
\hline 15. & 4,5 & 24 & 0,182 & D2a & L2 \\
\hline
\end{tabular}

Визначення видимих візуальних характеристик лісоматеріалів фіксували із врахуванням положень ТУ У 16.1-00994207-001:2018 Лісоматеріали круглі та пиляні. Візуальні характеристики. Класифікація, терміни та визначення, способи вимірювання. Технічні умови. Візуальні ознаки в круглих лісоматеріалах вимірювали в лінійних мірах та/або частках відповідних розмірів сортименту. За результатами огляду колод зафіксовано наявність тріщин, сучків, обдиру кори, механічних пошкоджень, уражень комахами, червоточин, грибних забарвлень, гнилизни (рис. 2).

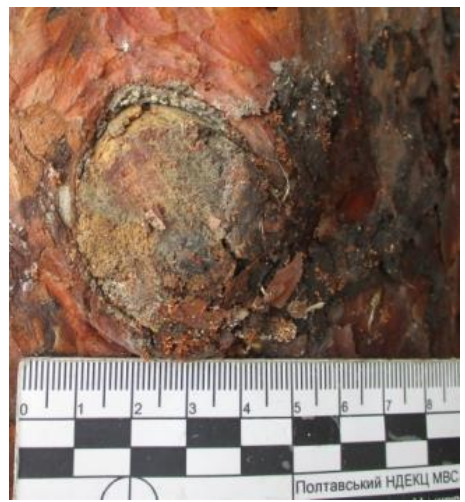

a)

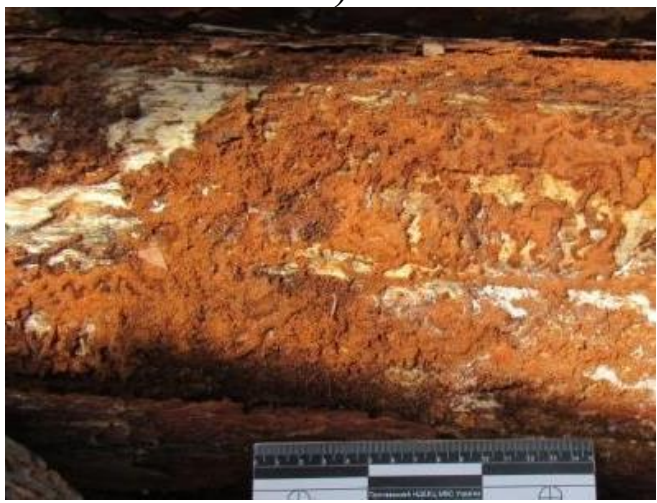

B)

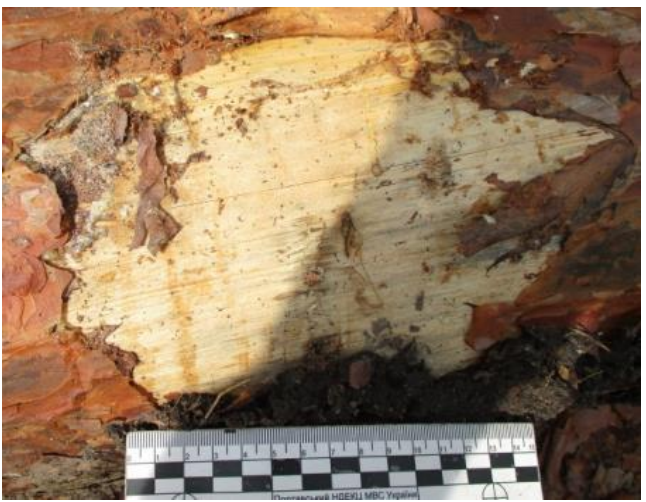

б)

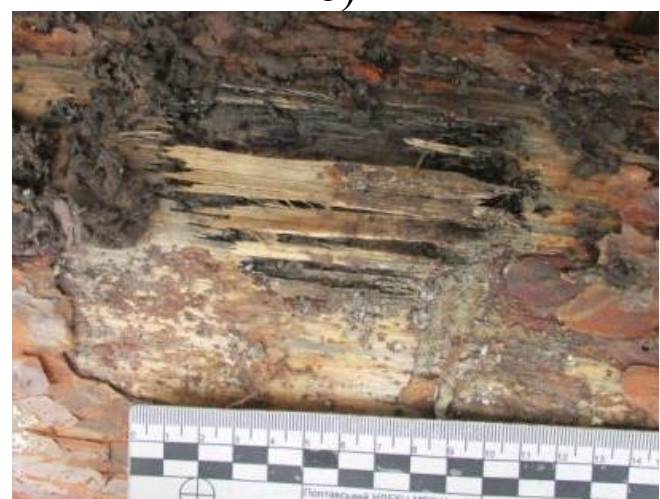

д)

Рис. 2. Зовнішній вигляд дефектів на одній із досліджуваних колод:

а) сучок; б) обдир кори, тріщини; в) грибні забарвлення, гнилизна, червоточина; д) механічні пошкодження, грибні забарвлення, гнилизна 
При визначенні вартості лісоматеріалів необхідно враховувати, що 31 січня 2019 року лісові господарства повинні використовувати національні стандарти, гармонізовані із стандартами $Є С$, в яких суттєво змінені підходи до визначення розмірно-якісних характеристик лісоматеріалів. До розмірно-якісних особливостей лісоматеріалів відносять довжину, діаметр, об'єм колод, візуальні характеристики (ознаки окремих ділянок лісоматеріалу, що впливають на якість деревини і обмежують можливості їі використання).

Так, положеннями ТУ У 16.1-00994207-003:2018 Лісоматеріали круглі хвойних та листяних порід. Правила класифікації. Технічні умови визначено, що кожна колода чи довгомірний лісоматеріал можуть бути сортовані в одному або у кількох класах якості, 3 використанням умовних позначок для поділу. Кожна колода, довгомірний лісоматеріал або комбінований лісоматеріал з умовним позначенням для поділу класифікують згідно 3 їх розмірами та зовнішнім виглядом, кількістю та розповсюдженням специфічних візуальних ознак за 4-ма класами якості (A, B, C, D), згідно 3 ДСТУ EN 1927-2:2018 Лісоматеріали круглі хвойні. Класифікація за якістю. Частина 2. Сосна.

Для визначення класу якості, відповідно до положень чинних нормативних документів, кожну колоду було класифіковано за іiі розмірами, зовнішнім виглядом, кількістю та розповсюдженням візуальних характеристик та ознак деревини. Під час сортування об'єктів дослідження були враховані всі зовнішні видимі візуальні характеристики. За встановленими візуальними характеристиками i ознаками деревини встановлено, що круглі лісоматеріали породи сосна відносяться до класу якості D.

На етапі аналізу застосування підходів до оцінки об'єкта, був здійснений вибір методів оцінки та проведення необхідних розрахунків. Процедура визначення вартості об'єктів дослідження регламентується Національним стандартом № 1 «Загальні засади оцінки майна і майнових прав» [4] та Законом України «Про оцінку майна, майнових прав та професійну оціночну діяльність в Україні» [5].

У відповідності до запитання, поставленого на вирішення експертизи, при дослідженні застосовувалася база оцінки, що відповідає ринковій вартості. Ринкова вартість - вартість, за яку можливе відчуження об'єкта оцінки на ринку подібного майна на дату оцінки за угодою, укладеною між покупцем та продавцем, після проведення відповідного маркетингу за умови, 
що кожна із сторін діяла із знанням справи, розсудливо і без примусу [4].

Відповідно до п. 14 Національного стандарту № 1 «Загальні засади оцінки майна і майнових прав» [4], визначення ринкової вартості об'єкта оцінки можливе із застосуванням усіх методичних підходів (дохідного, порівняльного, витратного) у разі наявності необхідної інформації.

Оскільки витратний підхід передбачає вирахування величини знецінення об’єкта дослідження в результаті всіх видів зносу, дані про які відсутні, та на момент дослідження розвинутий вторинний ринок подібного майна, застосування витратного підходу не є доцільним.

Застосування дохідного підходу при оцінці даного об’єкта дослідження за наявних вихідних даних суттєво ускладнено, оскільки відсутні необхідні відомості для здійснення прогнозу про фактичні та (або) очікувані доходи від найбільш ефективного використання об'єкта дослідження, включаючи дохід від можливого перепродажу.

При визначенні ринкової вартості об’єкта дослідження судовим експертом був використаний порівняльний методичний підхід, оскільки він передбачає аналіз цін продажу та пропонування подібного майна 3 відповідним коригуванням відмінностей між об'єктами порівняння та об’єктом оцінки, а у даному випадку ринок подібного майна досить розвинутий.

Відповідно до статті 11 Закону України «Про ціни і ціноутворення» [6] вільні ціни встановлюються суб' єктами господарювання самостійно за згодою сторін на всі товари, крім тих, щодо яких здійснюється державне регулювання цін. Тому вартість об'єкту експертизи, визначено з урахуванням встановлення на ринку міст України вільних цін на подібне до об'єкта дослідження майно, за інформацією з відкритих інформаційних джерел.

Ринкова вартість об'єктів дослідження установлюється як середня ринкова ціна на об'єкти, які за функціональним призначенням, споживчими властивостями і якістю максимально відповідають об’ єктам дослідження.

При визначенні ринкової вартості круглих лісоматеріалів хвойних порід порівняльним підходом було здійснено аналіз цінової інформації, що наявна на офіційних сайтах лісових господарств в конкретному регіоні в конкретний період часу (зазвичай лісгоспи оновлюють відпускні ціни на лісопродукцію один раз на квартал). Крім того, на даному етапі було проаналізовано дані, що характеризують економічні, соціальні, адміністративні та інші фактори, що впливають на ринкову вартість об'єктів дослідження та вивчено ринок лісоматеріалів, поточну кон’юнктуру і тенденції, а також здійснено підбір 
аналогів об’єктів оцінки. Ціна на круглі лісоматеріали хвойних порід зростає швидкими темпами, оскільки вагома частка лісової продукції експортується за кордон, що формує високий рівень цін на внутрішньому ринку. Основним фактором, що формує ціну на круглі лісоматеріали хвойних порід $є$ співвідношення ціни між сортиментами. Ціни на круглі лісоматеріали хвойних порід визначаються з урахуванням породи, класу якості, класу за діаметром та класу за довжиною.

Для вирішення запитання щодо визначення ринкової вартості круглих лісоматеріалів породи сосна судовим експертом проведений пошук цінової інформації у мережі Інтернет. Результати маркетингового дослідження систематизовано та викладено у таблиці 2.

Таблиця 2

\section{Визначення ринкової вартості об'сктів дослідження}

\begin{tabular}{|c|c|c|c|}
\hline \multicolumn{4}{|c|}{ Лісоматеріали круглі породи сосна класу D об’ємом 2,425 } \\
\hline Подібне майно & № 1 & № 2 & № 3 \\
\hline $\begin{array}{l}\text { Назва подібного } \\
\text { майна }\end{array}$ & $\begin{array}{c}\text { «Лісоматеріали } \\
\text { круглі сосна клас } \\
\text { якості D» } \\
\end{array}$ & $\begin{array}{l}\text { «PINS (сосна) PICA } \\
\text { (ялина) клас D» }\end{array}$ & $\begin{array}{c}\text { Круглі } \\
\text { лісоматеріали-Сосна } \\
\text { клас D»» }\end{array}$ \\
\hline $\begin{array}{l}\text { Ціна пропозиції, } \\
\text { грн за } 1 \text { м }^{3}\end{array}$ & 960,00 & 910,00 & 900,00 \\
\hline \multirow{2}{*}{$\begin{array}{l}\text { Джерело } \\
\text { інформації }\end{array}$} & $\begin{array}{c}\text { ДП «Фастівське } \\
\text { лісове } \\
\text { господарство» }\end{array}$ & $\begin{array}{c}\text { ДП «Семенівський } \\
\text { лісгосп» }\end{array}$ & $\begin{array}{c}\text { ДП «Тростянецьке } \\
\text { лісове } \\
\text { господарство» }\end{array}$ \\
\hline & $\begin{array}{l}\text { https://fastivlis.net/pr } \\
\text { aisi/lisomateriali- } \\
\text { krugli.html }\end{array}$ & $\begin{array}{l}\text { http://semlis.com.ua/ } \\
\text { proponujemo/praisi.ht } \\
\mathrm{ml}\end{array}$ & $\begin{array}{c}\text { http://www.trostles.co } \\
\text { m.ua/продукція-та- } \\
\text { ціни/ }\end{array}$ \\
\hline $\begin{array}{l}\text { Ринкова вартість, } \\
\text { грн }\end{array}$ & & $\begin{array}{l}, 00+910,00+900) / 3=92 \\
, 425 \times 923,33=2239,0\end{array}$ & \\
\hline
\end{tabular}

Завершальним етапом судово-товарознавчої експертизи лісоматеріалів круглих хвойних порід $\epsilon$ оцінка одержаних результатів проведеного експертного дослідження з письмовим оформленням її результатів.

Висновки та перспективи подальших досліджень. У процесі дослідження визначено чинники, що впливають на вартість круглих лісоматеріалів породи сосна, зокрема такі як довжина колоди, серединний діаметр й наявність дефектів, які у свою чергу визначають клас якості деревини, та об'єм колод без кори. Запропоновано алгоритм визначення ринкової вартості круглих лісоматеріалів хвойних порід за допомогою порівняльного методичного підходу, що включає порядок визначених дій, що однозначно призводять до вирішення поставленого завдання й організації та 
оптимізації роботи експерта. У ході проведення товарознавчої експертизи була визначена ринкова вартість лісоматеріалів круглих хвойних порід із застосуванням порівняльного методичного підходу. Результати експертизи оформлені у формі висновку експерта відповідно до «Інструкції з організації проведення та оформлення експертних проваджень у підрозділах Експертної служби Міністерства внутрішніх справ України», затвердженої наказом МВС України від 17.07.2017 № 591 із дотриманням вимог Кримінального процесуального Кодексу України.

Представлені результати досліджень являються початковим етапом визначення особливостей судово-товарознавчої експертизи круглих лісоматеріалів хвойних порід і потребують подальшого удосконалення й наукового обгрунтування досліджень лісоматеріалів щодо встановлення їх товарних властивостей та цінової інформації, що мають значення для вирішення завдань кримінального провадження про незаконні порубки лісу.

\section{Список використаних джерел}

1. Чураков Д. Б. Противодействие преступным посягательствам на сохранность лесных и иных насаждений (уголовно-правовые и криминологические меры): дис... канд. юр. наук: 12.00.08. Федеральное государственное казенное образовательное учреждение высшего образования «Академия генеральной прокуратуры Российской Федерации». Москва, 2017. 268 с.

2. Дудоров О. О., Письменський Є. О. Кримінально-правова кваліфікація незаконної порубки лісу: практичний посібник. Сєвєродонецьк, 2017. 213 с.

3. Державний класифікатор продукції та послуг: ДК 016:2010: прийнято та надано чинності Наказом Держспоживстандарту України від 11.10.2010 р. № 457: База даних «Законодавство України». Верхова Рада України. Режим доступу: https://zakon.rada.gov.ua/rada/show/v457a609-10\#n184 (дата звернення: 20.01.2020).

4. Національний стандарт № 1 «Загальні засади оцінки майна і майнових прав»: затверджений Постановою Кабінету Міністрів України від 10.09.2003 № 1440 // База даних «Законодавство України» / ВР України. Режим доступу: http://zakon0.rada.gov.ua/laws/show/1440-2003-\%D0\%BF (дата звернення: 20.01.2020).

5. Про оцінку майна, майнових прав та професійну оціночну діяльність в Україні: Закон України від 12.07.2001 № 2658-III // База даних «Законодавство України» / ВР України. URL: http://zakon3.rada.gov.ua/laws/show/2658-14 (дата звернення: 20.01.2020).

6. Про ціни і ціноутворення: Закон України від 21.06.2012 № 5007-VI // База даних «Законодавство України»/ ВР України. URL: http://zakon5.rada.gov.ua/laws/show/5007-17 (дата звернення: 20.01.2020).

\section{References}

1. Churakov, D. B. (2017). Protivodejstvie prestupnym posjagatel'stvam na sohrannost' lesnyh i inyh nasazhdenij (ugolovno-pravovye i kriminologicheskie mery). Extended abstract of candidate's thesis. Moskva [in Russian].

2. Dudorov, O. O., \& Pysmenskyi Ye. O. (2017) Kryminalno-pravova kvalifikatsiia 
nezakonnoi porubky lisu: praktychnyi posibnyk. Sievierodonetsk [in Ukrainian].

3. Derzhavnyi klasyfikator produktsii ta posluh: DK 016:2010: pryiniato ta nadano chynnosti Nakazom Derzhspozhyvstandartu Ukrainy (2010, October 11) // Baza danykh «Zakonodavstvo Ukrainy» / Verkhova Rada Ukrainy. Retrieved from: https://zakon.rada.gov.ua/rada/show/v457a609-10\#n184 (accessed January 20, 2020) [in Ukrainian].

4. Natsionalnyi standart № 1 «Zahalni zasady otsinky maina i mainovykh prav»: zatverdzhenyi Postanovoiu Kabinetu Ministriv Ukrainy (2003, September 10) // Baza danykh «Zakonodavstvo Ukrainy» / Verkhovna Rada Ukrainy. Retrieved from: http://zakon0.rada.gov.ua/laws/show/1440-2003-\%D0\%BF (accessed January 20, 2020) [in Ukrainian].

5. Pro otsinku maina, mainovykh prav ta profesiinu otsinochnu diialnist v Ukraini: Zakon Ukrainy (2001, July 12) // Baza danykh «Zakonodavstvo Ukrainy» / Verkhovna Rada Ukrainy. Retrieved from: http://zakon3.rada.gov.ua/laws/show/2658-14 (accessed January 20, 2020) [in Ukrainian].

6. Pro tsiny i tsinoutvorennia: Zakon Ukrainy (2012, June 21) // Baza danykh «Zakonodavstvo Ukrainy» / Verkhovna Rada Ukrainy. Retrieved from: http://zakon5.rada.gov.ua/laws/show/5007-17 (accessed January 20, 2020) [in Ukrainian].

Цель. Исследование теоретических и практических основ проведения судебнотовароведческих экспертиз с иелью определения рыночной стоимости лесоматериалов, в частности определение факторов, влияющих на стоимость кругльх лесоматериалов хвойных пород и обоснованные алгоритма определения рыночной стоимости кругльх лесоматериалов хвойных пород с помощью сравнительного методического подхода.

Методика. При проведении исследований, для определения рыночной стоимости круглых лесоматериалов хвойных пород, в комплексе применялись методы, в частности дедуктивный - при теоретическом обобщения проблемы, диалектический - при познании сущности явления незаконной порубки леса, исследовании его общих тенденций; монографический - для детальной конкретизачии научных основ определения рыночной стоимости кругльхх лесоматериалов хвойных пород; индуктивный и дедуктивный - для аргументации сформулированных в ходе исследований выводов, положений и перспектив дальнейших исследований.

Результаты. Рассмотрены вопросы использования специальных товароведных знаний в практике расследования уголовных дел о незаконных порубки лесных насаждений. Проанализирован механизм проведения судебно-товароведческой экспертизы для определения рыночной стоимости кругльх лесоматериалов хвойных пород. Обоснована целесообразность применения сравнительного методического подхода при проведении судебной товароведческой экспертизы с определением рыночной стоимости круглых лесоматериалов хвойных пород. В статье обоснован алгоритм определения рыночной стоимости круглых лесоматериалов хвойных пород при проведении судебнотовароведческой экспертизы, который предусматривает: идентификацию объекта исследования; отнесения объекта исследования к соответствующей классификационной группировке; установление количественных и качественных характеристик объекта исследования; выбор методов исследования и проведение необходимых расчетов; определение рыночной стоимости объекта исследования с помощью сравнительного методического подхода; оченка полученных результатов проведенного исследования $c$ 
письменным оформлением его результатов.

Научная новизна. В работе впервые обобщен и изложен комплекс проблемных вопросов, возникающих при использовании спещиальных товароведных знаний при проведении судебно-товароведческих экспертиз круглых лесоматериалов хвойных пород.

Практическая значимость. Предложенный $u$ апробированный алгоритм определения рыночной стоимости круглых лесоматериалов хвойных пород может быть использован при проведении подобных судебно-товароведческая экспертиза.

Ключевые слова: незаконные порубки, нелегальный оборот древесины, древесина, круглые лесоматериаль, товароведческая экспертиза, рыночная стоимость.

Purpose. Investigation of theoretical and practical bases of forensic expertise in order to determine the market value of timber, in particular to determine the factors affecting the value of coniferous timber and substantiate the algorithm for determining the market value of coniferous timber.

Methodology. During the research, to determine the market value of coniferous timber, complex methods were applied, in particular deductive - during the theoretical generalization of the problem, dialectical - in the knowledge of the nature of the phenomenon of illegal logging, the study of its general tendencies; monographic - for detailed specification of scientific bases for determining the market value of coniferous timber; inductive and deductive - to substantiate the conclusions drawn in the course of the research, the provisions and prospects for further research.

Findings. The use of special knowledge in the practice of investigating criminal cases of illegal logging has been considered. The mechanism of forensic examination to determine the market value of coniferous timber is analyzed. The expediency of applying the comparative methodological approach in carrying out forensic examination with the determination of the market value of round coniferous timber is substantiated.The article substantiates the algorithm for determining the market value of coniferous timber during the forensic examination, which provides for: identification of the object of study; assigning the research object to the relevant classification group; establishing quantitative and qualitative characteristics of the object of study; choice of research methods and necessary calculations; determining the market value of the research object using a comparative methodological approach; evaluation of the results of the conducted research with a written registration of its results.

The scientific novelty. For the first time, a set of problematic issues arising from the use of special commodity knowledge during forensic examination of round coniferous timber is summarized and outlined.

The practical value. The proposed and tested algorithm for determining the market value of coniferous timber can be used during such forensic examinations. The materials and materials of the article can be used by experts of expert organizations for consideration in the work during carrying out forensic examinations.

Keywords: illegal logging, illegal timber trafficking, timber, round timber, commodity expertise, market value.

Стаття рекомендована до публікаиії кандидатом економічних наук, провідним фахівием відділу забезпечення Полтавський науково-дослідного експертно-криміналістичного изентру Марчишинець $O$. Стаття надійшла в редакиію 30.12.2019 р. 